\title{
Representation and Austerity Politics: Attitudes of Greek Voters and Elites Compared
}

\section{Georgios Karyotis}

(University of Glasgow)

\section{Wolfgang Rüdig}

(University of Strathclyde)

and

\author{
David Judge \\ (University of Strathclyde)
}

\begin{abstract}
Drawing on surveys of voters and MPs in Greece, this article analyses elite-mass interaction on key policy (austerity, European integration, immigration) and ideological issues after the 2012 elections. We find that while for the government parties, New Democracy and PASOK, the level of congruence is quite high, MPs from opposition parties (SYRIZA, Golden Dawn) place themselves in more exposed positions in comparison with their voters. The observed substantial variation in the intensity and direction of congruence, across parties and issue preferences in Greece, reinforces the view that the dimensionality of political contestation is not reducible to a single ideological dimension.
\end{abstract}

\section{Journal: South European Society and Politics}

Publication Date: December 2014 (special issue)

Karyotis, G., W. Rudig and D. Judge (2014) 'Representation and Austerity Politics: Attitudes of Greek Voters and Elites Compared', South European Society and Politics, Vol. 19, No 4, pp. $435-456$.

Permalink: $\underline{\text { http://dx.doi.org/10.1080/13608746.2014.977478 }}$

** This is the pre-publication copy of the article ** 


\section{About the Authors}

Georgios Karyotis is Senior Lecturer in International Relations at the University of Glasgow and Secretary of the Greek Politics Specialist Group (GPSG) of the Political Studies Association. His research interests include securitisation theory, migration, terrorism, political behaviour and austerity politics. Georgios Karyotis, School of Social and Political Sciences, Adam Smith Building, 40 Bute Gardens, University of Glasgow, Glasgow, G12 8RT, UK; Tel: 0044141330 3384; email: georgios.karyotis@glasgow.ac.uk

Wolfgang Rüdig is Reader in Politics at the University of Strathclyde. His main interest is the study of both conventional and unconventional political behaviour, including voting, party membership and activism, as well as the involvement in social movements and protest. Wolfgang Rüdig, School of Government and Public Policy, University of Strathclyde, 16 Richmond Street, Glasgow, G1 1XQ, UK; Tel: 0044141548 2918; email: w.rudig@strath.ac.uk

David Judge is Emeritus Professor of Politics at the University of Strathclyde. His main research interests are legislative studies, representative democracy, especially parliamentary institutions, representative theories and issues of democratic legitimacy. His latest book is Democratic Incongruities (Palgrave 2014). David Judge, School of Government and Public Policy, University of Strathclyde, 16 Richmond Street, Glasgow G1 1XQ, UK; Tel: 0044141 548 2365; email: d.judge@ strath.ac.uk

\section{Acknowledgements}

Financial support for the data collection was provided by the British Academy under its small grants programme; Principal Investigator: Georgios Karyotis. Previous versions of this paper were presented in conferences in Bordeaux, Lisbon and Thessaloniki. We are most grateful to conference and survey participants, Phoebe Kouvela for research assistance and the journal's guest editors and referees for their insightful comments. More details can be found on the project's website at www.AusterityPolitics.net. 


\section{Introduction}

One of the most commonly used measurements of the quality of a democracy is the extent to which the positions of party elites and their supporters correspond across issue and ideological divides, which marks the degree of representation that exists within the system. An important tool to evaluate the performance of representative democracy is the concept of congruence. Policy or ideological congruence between political parties and their voters has been linked to higher levels of accountability and legitimacy and to higher levels of satisfaction with democracy. A low level of congruence on the other hand might signal the voters' eventual withdrawal of support for a party in favour of others that most closely match their preferences on salient issues.

Despite being at the centre of empirical political science research for well over half a century, what exactly constitutes 'congruence' and how it is measured has remained open to contestation. For many, the degree of left-right congruence between electors and those elected is 'crucial' to the understanding of the quality of political representation (e.g. Huber \& Powell 1994, p. 295; Freire \& Belchior 2013). For others, an almost exclusive focus on the ideological dimension leads to a 'blind corner' of political representation research to the extent that it might 'conceal voters' unequal representation across issue dimensions' (Thomassen 2012, pp. 14-15). The post-2009 economic crisis in Europe provides a renewed impetus to study the quality of representation, with elite-voters positioning on austerity, arguably, emerging as a key and separate dimension of congruence.

In stable Western European democracies, the reported decline in the level of voter-party congruence on distributive policies could be seen as a rather abstract measurement that might have implications for the long-term development of political systems. In the case of the major economic crises experienced in Southern Europe since 2010, the question of the extent to which elected representatives adequately reflect the views of their voters takes on a more existential character. Can democratic regimes in Southern Europe survive the Eurozone crisis, particularly when unpopular austerity measures are being adopted and external actors such as the International Monetary Fund (IMF) and the European Central Bank (ECB) emerge as key stakeholders in the domestic policies of crises-ridden states? To what extent do the austerity policies promoted by parties in government and those promoted by parties in opposition reflect the views of their respective voters? Do domestic democratic priorities still matter in this context, or are they a mere illusion with decisions effectively made in Brussels, New York, Frankfurt or Berlin?

This article explores these questions by focussing on elite-mass interaction on key policy and ideological issues under conditions of extreme austerity. Greece is used as a case study, as the country most severely affected by the Eurozone crisis, whose economic 'salvation' was largely appropriated by the so-called 'troika', i.e. the IMF, the ECB and the European Commission, which provided loans of $€ 110$ billion in May 2010 and $€ 130$ billion in October 2011. The centrality of unelected actors in the management of the Greek debt crisis, combined with the parallel collapse of public trust in domestic political institutions, rising dissatisfaction with democracy (Verney 2014) and mass anti-austerity protest (Rüdig \& Karyotis 2014) signify a possible representation crisis that has thus far been left largely unexplored. 
The analysis draws on original panel data of voters, mainly on a third wave collected in June 2012, and an elite survey of Greek MPs conducted in July 2013 to answer the following questions: First, how well do parties represent the ideology of their voters? The scarcity of surveys of citizens and, particularly, of MPs in Greece means that this article offers a unique assessment of the country's ideological and political spectrum and quality of democracy at a time of major political realignment. Second, how well do parties represent the attitudes of their voters on key policy issues? The focus here is on the key dimensions that have dominated public debates in Greece since the debt crisis erupted in early 2010. These are centrally about attitudes to austerity policies but also include the positioning of voters and MPs on other matters such as immigration and European integration, which became highly salient in the run-up to, and after, the 2012 Parliamentary elections and indicate broader value judgements that might not necessarily be correlated with economic or ideological attitudes. Third, to what extent do congruence patterns vary among parties and across dimensions of political conflict? The limited prior empirical research on cross-dimensional aspects of congruence offers an opportunity for an exploratory analysis.

The structure of the paper is as follows: the first section engages with conceptual debates and ambiguities in relation to representation and proposes a four-dimensional framework to study congruence in the context of economic crisis and austerity politics. The second section draws upon these debates to identify key research hypotheses. The third section discusses methodological and data collection issues. Survey findings are presented in the fourth section, focussing on levels of elite-public congruence across a range of issues and discussing the implications of these findings. The overall analysis contributes to our understanding of the implications of austerity politics in Greece and beyond, while also addressing broader questions about the impact of the economic crisis on the quality of democracy and representation.

\section{Representation and Austerity Politics}

Political representation presupposes some linkage between the inputs (in terms of the articulation of the preferences, opinions or interests of the represented) and the outputs of the political process (in terms of collective decisions made by representatives in the form of public policies). The exact form this linkage takes is varied and has led to protracted conceptual and empirical contestation, but the form of primary concern for the present analysis is the reflection of the policy preferences of the represented in the policy preferences of their representatives. In other words, there is an assumption, variously, of "policy congruence', 'issue congruence', 'ideological congruence', 'issue representation' or 'policy responsiveness' (see Andeweg 2011, p. 39; Walgrave \& Lefevere 2013, p. 459) embedded within conceptions of electoral representation. This section engages with the relevant literature with a view to identifying the most pertinent dimensions of congruence that will be central to understanding political representation in the context of austerity politics and the Greek crisis.

The most common approach to assess policy congruence is to compare 'the median voter with the position of the median legislator' (Andeweg 2011, p. 40). One basic problem with the use of measures of central tendency is the loss of information resulting from cases where the same mean or median is derived from very different distributions (see Pierce 1999, pp. 14-15). Other problems include the fact that mean voter issue positions and elite issue 
positions are not necessarily conceptually analogous, and that the mean position of a party's voters may be closer to the mean position of the elite of another party than to the party they voted for. To overcome many of these difficulties, the present study seeks to discover the policy positions of voters and elected representatives alike by surveying them directly and asking them to position themselves on both a left-right scale and on issue scales. In this sense, this data collection strategy falls into, what Andeweg (2011, p. 40) calls, a 'relatively rare' category.

The question that arises is what dimensions should be included in our analysis of elite-mass interaction under conditions of extreme austerity, such as those found in Greece? The starting point is clearly a focus on the ideological dimension. The left-right scale 'captures the comparative ideological positions of citizens and parliamentarians reasonably well' (Belchior 2010, p. 124) and offers a 'progressive and redistributive view of the role of the state against a more conservative and market-oriented state outlook' (de Vries, Hakhverdian \& Lancee 2013, p. 223). For these reasons, left-right scales have been used widely as survey instruments in the study of representational congruence (Huber \& Powell 1994; Schmitt \& Thomassen 1999, Golder \& Stramski 2010; Belchior 2010; Freire \& Belchior 2013).

However, the extent to which self-placement on left-right scales adequately captures the full range of issue positions has come into question for three main reasons. First, there are potential problems associated with ambiguities in the way that 'left' and 'right' are perceived by different voters, and between voters and their representatives - to the extent that mass and elite positioning on the left-right scale is not necessarily conceptually analogous (Pierce 1999, p. 14). For elites, particularly of ideologically extreme parties, self-placement in the two ends of the ideological spectrum might be strategically avoided (see Lefkofridi \& Casado-Asensio 2013). For voters, inconsistency and incoherence in their belief systems and ideological preferences (Walgrave \& Lefevre 2013, pp. 462-463) may impair their left-right positioning. In Southern European states in particular, where levels of education, media exposure and clarity of party policy alternatives are comparatively low (Freire \& Bechoir 2013, p. 2), lower levels of recognition of the left-right dimension have been observed than in the more established democracies in Western Europe (Freire 2008, p. 202).

Second, a left-right scale taps primarily into economic issues, most closely associated with questions about the redistribution of wealth, taxing and spending, and the role of the state in the economy (see Hooghe, Marks \& Wilson 2002; Dalton, Farrell \& McAllister 2011; Costello, Thomassen \& Rosema 2012). But although associated with such economic questions, the left-right scale calibrates broader general ideological orientations to these issues rather than substantive policy preferences as such (Belchior 2010, p. 124). The blurring of traditional ideological divides in Greece demonstrates the limitations of making assumptions about a party's economic policy based on its members' self-placement on the left-right scale. The austerity measures and bailout agreements were first introduced by the

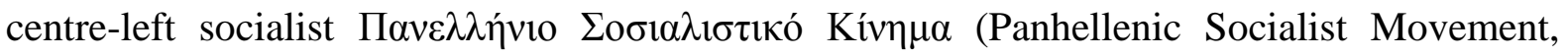

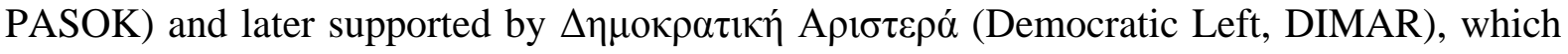

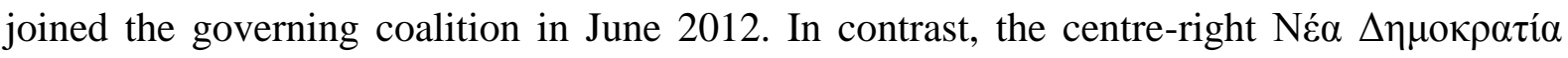
(New Democracy, ND) party, while in opposition, was critical of welfare retrenchment, before itself making a U-turn, joining a pro-austerity coalition government in November 2011 and later winning the June 2012 elections. On the left, PASOK has competed with the

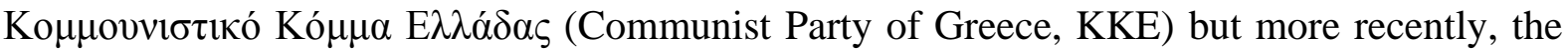




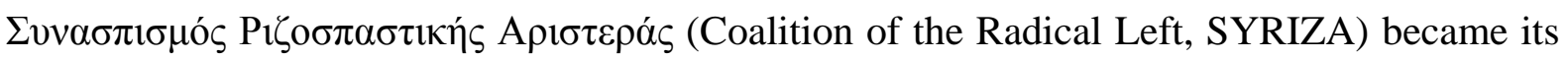

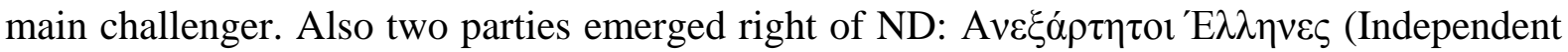

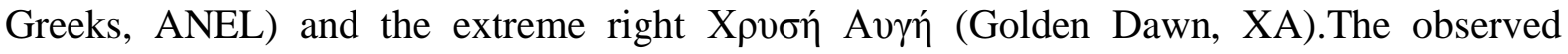
mismatch between party ideology and expected positioning on austerity clearly points towards the need to look in closer detail at elites and voters' substantive policy preferences in the economic and other dimensions, particularly at such times of high volatility.

Third, and related to the above, the 'unidimensionality' of the left-right scale is questioned along with the extent to which policy issues and preferences are constrained by this dimension. Some analysts have identified non-economic dimensions of political contestation, called variously liberal-authoritarian (Kitschelt 1994), or green/alternative/libertarian versus traditional/authoritarian/nationalist (Hooghe, Marks \& Wilson 2002; Hooghe \& Marks 2008), which is associated with socio-cultural values and the politics of identity. These two dimensions of political conflict, broadly economic and socio-cultural, are often deemed to be essentially orthogonal (van der Brug \& van Spanje 2009; Lefkofridi, Wagner \& Willmann 2014, p. 79). Therefore, to compress political analysis into a single left-right dimension is 'an oversimplification' (Dalton, Farrell \& McAllister 2011, p. 86) that cannot adequately capture their representation across issue dimensions (Thomassen 2012, pp. 14-15).

The above discussion has highlighted the limitations of relying solely on left-right measurements to study represented-representative congruence. A further challenge is that the majority of prior studies have used either issue preferences or left-right self-placement, or deployed the latter as a proxy of the former. Rarely have the two measures been used together, other than in the works of Belchior (2010, 2014), Freire \& Belchior (2013) and Costello, Thomassen \& Rosema (2012). Our study of representation in Greece in the context of economic crisis builds on these attempts to incorporate different dimensions of congruence in a single framework. The choice of dimensions derives both from the existing literature discussed above and the specific national context and economic crisis conditions. The result is an exploratory four-dimensional framework that captures both ideological and issuespecific policy areas that have dominated public debate since the crisis erupted.

The first dimension to be included in our study is the ideological one, using the traditional left-right self-placement on a 0-10 scale. Given that this cannot reliably capture attitudes to specific policy alternatives and highly politicised issues, as discussed, we also use batteries of issue positions to tap substantive issue preferences and include additional dimensions of congruence. A key difference of this article from preceding studies of issue congruence is its specific focus upon attitudes to austerity and economic crisis. This represents the second dimension of our study, explored in its own right and not as a proximate left-right 'economic' indicator.

Any crisis typically generates a contest between competing frames concerning its nature and severity, the responsibility for its occurrence or escalation, and appropriate responses to curtail its development (Entman 1993). The crisis in Greece divided voters and parties into two main camps: those in favour of austerity and those against it. Central to the initial attempt of pro-austerity elites to legitimise the unprecedented austerity measures was a depiction of the debt crisis as an existential threat of exceptional urgency, which undermined both the economic and political order and the country's prospects of remaining a member of the Eurozone (see Karyotis \& Rüdig 2013). To measure the level of elite-voters' congruence on 
the austerity dimension, we thus ask two questions, one about its severity and another, more specifically, about the degree of acceptance of austerity measures in order to ensure Greece's continuing membership of the European currency. The latter is used as a proxy to map austerity attitudes, given that it captures one of the core dilemmas that dominated the 2012 Parliamentary elections.

Related to this, our third dimension concerns attitudes to European integration. The sluggish, fragmented and largely punitive response by the EU in the early stages of the Greek debt crisis divided political parties and voters on their trust and support for the European integration project (Clements, Nanou \& Verney 2014; Papadimitriou \& Zartaloudis 2015). In parallel to the austerity debate was the question of whether the European orientation of Greece could be sustained or was even desirable, at a time when European institutions were centrally involved in dictating unpopular domestic reforms. To measure this dimension, we use a question on whether European unification should be pushed further or has gone too far, using the 0-10 scale, a question widely used in (European) electoral and candidate studies.

Our fourth dimension taps into socio-cultural aspects. Questions about authoritarianism vs. libertarianism were considered but do not seem to work in the Greek case - both MPs and voters struggled to position themselves coherently in relation to these questions. What we focus on instead is immigration, which surprisingly emerged as one of the most salient topics in the run up to the 2012 elections (Karyotis \& Skleparis 2013), with repercussions for the revival of nationalism and increase in support for far-right parties like Golden Dawn. To measure immigration attitudes, we rely on two standard questions used in cross-national surveys exploring the extent to which migrants increase criminality and have a positive effect on the Greek economy, using a 0-10 scale (see question wording in Appendix).

\section{Research Hypotheses}

The evaluation of representational congruence in this article covers four dimensions (leftright ideology, austerity, Europe and immigration). Our approach is to an extent exploratory, since no clear tendency or pattern has been identified in previous studies of MP-voter congruence (Belchior \& Freire 2013, p. 276), with the degree of congruence varying according to issue dimensions (Belchior 2010, p. 124). Some preliminary hypotheses derived from the literature are presented below and explored in the empirical discussion.

Studies of issue linkage between voters and parties, focussing specifically on left-right congruence, reveal that party representatives tend to hold more pronounced ideological positions than their electorates (Dalton 1985, p. 275, Belchior 2010, p. 125). The first hypothesis, pertaining to the left-right dimension, is thus:

H1: Greek MPs will typically hold a more pronounced ideological position than their voters.

This pronounced positioning is particularly found for parties on the right and even more so for parties on the left (Dalton 1985, p. 275, Esaiasson \& Holmberg 1996, pp. 92-95, Thomassen 1999, p. 46-50). Hence, an associated postulate is that 'centrist' parties, centreright or centre-left parties appealing to the broader electorate which might be called 'catch- 
all' parties (Kirchheimer 1966), are more congruent with the preferences of their supporters. This factors 'party type' into explanations of congruence. Indeed, one pronounced theme in the literature is that catch-all parties, with an emphasis upon short-term vote-maximising strategies, will display higher levels of congruence than more ideologically extreme parties pursuing longer-term strategies of social mobilisation (see for example Iversen 1994, pp. 173177; Holmberg 1989, p. 12; Belchoir 2012, p. 356; Belchior \& Freire 2013, pp. 276-277). This leads us to our second hypothesis:

H2: Higher levels of ideological congruence will be observed between voters and representatives of the 'centrist parties' (New Democracy and PASOK), than for 'ideological parties' on the left (especially SYRIZA) and on the right (Golden Dawn).

In terms of the second dimension - positioning with regard to austerity policies - attitudes on the part of citizens and the policy positioning of political parties in responding to crisis can be expected to reflect fundamental macroeconomic divisions. Indeed, Maatch (2014, p. 99) when examining the factors accounting for the positioning of political parties on macroeconomic anti-crisis measures in the Eurozone, starts from the initial premise that: 'parliamentary parties opt for macroeconomic measures which coincide with their general economic ideology: parties located on the economic "right" opt for neoliberal measures whereas parties located on the economic "left" advocate Keynesian ones'. In the context of the Eurozone crisis, however, a reasonable expectation is that: "parliamentary parties in states that received a bailout are more inclined to opt for Keynesian anti-crisis measures' (2014, p. 101). The underpinning assumption is that voters in bailout states 'strongly disapprove of austerity measures' and are more likely to welcome Keynesian anti-crisis measures (2014, p. 101). In which case parties, as a vote-seeking strategy, would be constrained in their stated preferences for austerity measures. Yet, Maatch (2014, p. 100) is also aware that institutional factors, particularly the divide between parties in government and parties in opposition, may impact on macroeconomic preferences. In which case, the proposition can be made that parties in government are more likely to support austerity policies, while opposition parties are expected to propose counter-austerity measures (Maatch 2014, p. 100).

H3.1: MPs are constrained in their positioning on austerity measures by their perceptions of voter antipathy to EU-imposed austerity policies.

H3.2: MPs of opposition parties will adopt stronger anti-austerity positions than MPs and voters of parties in government.

Given the dominant role played by the EU in managing the crisis, one key question in Greek politics is how parties and voters are positioned in their respective attitudes to the European Union. Existing research suggests that attitudinal and policy positioning in relation to EU integration are not necessarily constrained by the left-right dimension (Costello, Thomassen \& Rosema 2012, p. 1230). Existing studies have also found that parties adopting anti-EU positions are typically located closer to the extremes of the left-right dimension, whereas centrist parties have displayed more positive attitudes to EU integration (Rosema \& de Vries 2011, pp. 210-11, Costello, Thomassen \& Rosema 2012, p. 1230). Lefkofridi \& CasadoAsensio (2013, p.107) found, however, that parties of the ideological left hold positions closer to the broader electorate on the EU dimension than do parties of the ideological right. Generally, political elites have been more supportive of EU integration than voters 
(Steenberg, Edwards \& de Vries 2007). Yet, the complexity of public attitudes towards the EU, and the change in those attitudes, should also be noted. In the case of Greece, successive Eurobarometer surveys, between 2009 and 2013, revealed a tripling of the negative image of the EU, a doubling of the belief that the EU was going in the wrong direction, as well as a doubling of level of mistrust in the EU. In the same period, however, positive attitudes towards the euro increased and remained well above the EU average after the 2012 elections. The hypotheses that can be formulated from the existing literature are thus:

H4.1: Parliamentary elites will be more supportive of EU integration than their voters.

H4.2: Centrist parties will display more positive attitudes to the EU than more ideologically extreme parties, and voters and parties of the ideological right will display most anti-EU positioning.

The fourth dimension - positioning in relation to immigration - has become of increased salience in most EU states (Lefkofridi \& Horvath 2012, p. 29, Thomassen \& van Ham 2014, p. 415). Early academic studies assumed that public positioning was generally anti-immigrant and that party positions on immigration were either absent or lacked diversity (see Freeman 1995). More recent studies, however, have assumed that there is a diversity of public attitudes to immigration, and that parties do position themselves on immigration matters with something of an anti-immigrant bias (Lefkofridi \& Horvath 2012, p. 310; Karyotis \& Skleparis 2013). In the case of Greece, Lefkofridi \& Horvath (2012, p. 36) found that the average citizen position was more restrictive than the average position of the political parties on immigration. The hypotheses to be examined therefore are:

H5.1: Voters will adopt stronger anti-immigration positions than their political representatives.

H5.2: Parties of the extreme right will be more congruent with their voters on the sociocultural/immigration dimension than parties of the extreme left.

\section{Data Collection}

To enable the direct comparison of ideological positions, issue preferences and attitudes, surveys, using identical questions, were undertaken for both voters and parliamentary representatives. Data on voters were collected through a telephone survey, conducted immediately after the June 2012 Parliamentary elections, using stratified quota sampling. The survey was carried out by a polling organisation, Kappa Research, and was part of a threewave panel study, with earlier measurements in December 2010 and December 2011. In the first wave, a dataset with a total of 1014 valid responses was generated that was representative of the distribution of the Greek adult population in terms of geographical location, gender and age. With high levels of attrition, a total number of 481 valid responses were collected in the third wave, which is most relevant to the current study. An analysis of the effects of attrition has not revealed any significant non-response bias.

A survey of current Greek MPs was carried out in July 2013. In the first instance, a list of email addresses was compiled on the basis of information provided by the Office of the General Secretary of the Hellenic Parliament and other sources. All 300 MPs were contacted by email, and electronic reminders and follow-up phone calls were used to increased response rates. A major problem, however, was that many of the email addresses provided were 
incorrect or were not monitored by the targeted MP. To boost participation further, therefore, a research assistant conducted the survey face-to-face with MPs in Parliament. The combined surveys produced a total of 52 responses. In a further step, a link to an anonymous survey was provided which enabled MPs to complete the questionnaire without revealing their identity. This resulted in a further 25 MPs completing the survey anonymously, of whom 20 revealed their party affiliation. Members of all parties responded, with the exception of the Communist Party KKE, who refused to do so without explanation.

--- Table 1 about here ---

In total 77 responses were obtained, a response rate of 26.7 per cent (excluding KKE). This article focuses on the 72 MPs for whom their party affiliation is known (see Table 1). The response rate varied greatly between parties, with particularly high response rates from MPs of the opposition parties ANEL and DIMAR. The response rates were particularly disappointing for MPs from the government parties New Democracy and PASOK. One possible explanation is that government MPs were reluctant to express positions that might have distanced them from their official party lines. Since many of the questionnaires were completed anonymously, it was not possible to use published data on the background of MPs to determine non-response bias. Overall, our response rate is in line with those of other surveys of MPs that were recently conducted in other European countries (cf. Deschouwer \& Depauw 2014). Detailed analyses of surveys of political activists with low response rates suggests that any non-response bias is usually limited (Rüdig 2010).

\section{Ideological and Policy Congruence in Greece}

Opposition to austerity has come from both the left and the right. An important question relevant to our first dimension of representation concerns the extent to which the crisis has resulted in ideological incongruence or significant ideological radicalisation at both ends of the spectrum. To explore this, we asked voters and MPs to locate themselves on an 11-point scale from 0 'left' to 10 'right'. The scores on the 0-10 scales are displayed for each party in the boxplots in Figure 1(a). Included are all parties with MPs; the KKE is included but as its MPs refused to take part in the survey, only voters' data is available. In addition, we conducted further statistical analyses to test whether any differences in the positioning of voters and MPs are statistically significant. ${ }^{1}$

\section{--- Figure 1 about here ---}

With the exception of Golden Dawn, representatives from all other parties self-place themselves in a more extreme ideological position than their supporters. This effect is most pronounced and statistically significant for SYRIZA, in line with the literature and hypothesis $\mathrm{H} 1$ that suggests that ideological parties, particularly on the left, are more likely to remain loyal to their ideological positions than centrist parties, which might make adjustments to their message based on short-term electoral calculations (Pierce 1999; Belchior 2012; Önnudóttir 2014). While SYRIZA's MPs firmly position themselves on the left, their voters are considerably more moderate. Clearly, in 2012 SYRIZA attracted many voters who were unhappy with the policies pursued by PASOK, but these voters on the whole did not place themselves on the extreme left. 
As posited in H2, the centrist parties, New Democracy and PASOK, are the most congruent, as is typically the case across the EU (Belchior 2012). On the right, Golden Dawn is the most right-wing party but, remarkably, neither their voters nor their MPs position themselves on the extreme right. About half of Golden Dawn voters and MPs place themselves in a centre position, perhaps in a strategic attempt to defuse and reject the extreme-right label ascribed to them or, more likely, indicative of the ambiguities in the way they perceive 'left' and 'right'. The overall picture suggests that, even in conditions of austerity and crisis, electors including DIMAR, SYRIZA and PASOK supporters - positioned themselves close to the ideological centre. Only KKE voters position themselves towards the far left.

Irrespective of the ideological dimension, the dominant issue of Greek politics since 2010 has been the austerity crisis. Greek political parties have offered competing narratives on both its severity and the necessity for extreme austerity measures. On its severity, we asked voters and MPs to assess on a scale of 0 to 10 how serious they considered the threat. At one end of the scale was the statement that the threat was exaggerated (0). At the other end of the scale (10) the argument was posed that Greece's national survival is seriously at risk - an argument made repeatedly by the pro-austerity camp in order to legitimise the measures (see Karyotis \& Rüdig 2013). Overall, both voters and MPs considered the threat to be very serious, but MPs had a slightly stronger perception of threat, as compared with voters (means 7.18 MPs, 6.35 voters; statistically significant at $\mathrm{p}<0.001) .^{3}$

Does the level of congruence vary across parties with regards to the severity of the threat? The scores on the 0-10 scales are displayed for each party in the boxplots in Figure 1(b), which demonstrates a broad range of views in the general public of all political persuasions. The difference between voters and MPs was particularly marked for the main opposition parties SYRIZA, Independent Greeks and Golden Dawn. Their MPs saw the threat as particularly great. MPs of the government parties New Democracy, PASOK (and DIMAR) on the other hand appeared to be somewhat more relaxed about the threat involved. This is rather surprising as it represents a reversal of positions between the two camps compared to their rhetoric at the early stages of the crisis. A plausible explanation is that members of the governing coalition, three years after the crisis erupted, wanted to communicate a message of successfully managing and arresting the crisis, in an attempt to secure future electoral gains.

A closer look at the level of congruence on the austerity dimension is displayed in Figure 1(c). We asked voters and MPs to rate their attitudes to austerity policies on a scale of 0 and 10 , with ' 0 ' standing for abandoning austerity policies, even if this risked leaving the Eurozone, and '10' for accepting austerity measures and do whatever it takes to remain within the Eurozone. Figure 1(c) reveals divergences in the level of support for austerity measures between voters for the main government parties and voters for the opposition parties. Support for austerity policies was strongest among voters of the two government parties New Democracy and PASOK. Overall, even these voters offered relatively lukewarm support (ND mean 6.50; PASOK 6.43). Initially, DIMAR had also been a member of the government, led by ND-leader Antonis Samaras, but decided to leave the coalition in June 2013, just before our MP survey was conducted. DIMAR voters were not very supportive of austerity policies (mean 5.05), and thus the party's decision to leave the government looks to have been in line with the wishes of their voters (and in accordance with H3.1). 
Our results also reveal that there was little difference between the attitudes of voters and MPs respectively for ND and PASOK. The contrast between the attitudes of voters and MPs was far stronger for the main opposition parties. Here, the views of MPs were far more clearly anti-austerity than their voters. This applies to a virtually identical degree to SYRIZA, the Independent Greeks and Golden Dawn. With SYRIZA becoming the main opposition party in the 2012 elections and the main challenger against the pro-austerity government, the gap between MPs positioning themselves as strong opponents of austerity and SYRIZA voters displaying more moderate positions (means 1.88 for MPs and 3.51 for voters, statistically significant at $\mathrm{p}<0.05$ level) may be seen as particularly significant. These findings challenge H3.1 to the extent that voters in our sample were more likely to approve of austerity measures than their representatives, yet at the same time the findings offer support for H3.2 that MPs from opposition parties adopt stronger anti-austerity positions than MPs and voters of parties in government.

The third dimension in our framework examines how voters and parties are positioned in their respective attitudes to the European Union. A particularly pertinent question is whether there is a gap between parliamentary parties and their voters in their positioning in relation to EU integration? The significance of this question was only heightened given the interventionist role of the EU in the imposition of austerity programmes in Greece. To measure attitudes to EU integration we asked voters and MPs to locate themselves on another 11-point scale, from opposition to further unification (0) to demands for unification to be pushed further (10).

The results shown in Figure 1(d) indicate, against the expectation of H4.1, that there is no major difference between voters and MPs on European integration for most parties. ND and PASOK supporters are generally pro-EU. DIMAR is one case where there is a major difference between voters and MPs, as voters display considerably lower support for EU integration than their representatives. Among the main opposition parties, there are major differences (basically in line with H4.2). Golden Dawn is the party most hostile to the EU. ANEL supporters and MPs display a broad range of views, as do SYRIZA supporters and MPs. As a party challenging for leading an alternative government, the attitudes shown by SYRIZA show a certain ambiguity. Overall, the majority of SYRIZA voters and MPs are clearly pro-EU, but anti-EU views also are present. In that sense, MPs represent the range of views held by the party's supporters.

The fourth dimension in our analysis - positioning in relation to immigration - has, as noted above, become of increased salience in most EU states. Certainly in the case of Greek politics the issues of immigration and austerity have become inextricably intertwined (Karyotis \& Skleparis 2013). To measure levels of congruence on this issue, we constructed an index of the degree of agreement/disagreement, which was derived from two contrasting statements on immigration: 'immigrants are generally good for the Greek economy', and 'immigrants increase crime rates'. Utilising the answers to these statements, an 11-point scale was created (Figure 1(e)) to facilitate comparisons with the other results. ${ }^{4}$

On this issue, the MPs of Golden Dawn predictably adopted strong anti-immigration positions, with all MPs positioning themselves at the extreme end of the scale. Golden Dawn voters took a clear, but less extreme, anti-immigration position than their representatives. 
Similarly for ANEL, a right-wing opposition party, MPs displayed more pronounced antiimmigrant attitudes than their voters. Thus, in the case of these two parties, H5.1 was not sustained. Voters of other parties displayed a broader spread of positioning than their representatives, with anti-immigration attitudes evident in voters for all parties. SYRIZA voters in particular adopted a more pronounced anti-immigration position than their representatives in parliament.

--- Table 2 about here ---

What then can we say on the basis of these comparisons about the determinants of policy congruence? In Table 2, we present the results of both bi-variate and multi-variate statistical analyses comparing voters and MPs. In the bi-variate analysis, the differences of means between voters and MPs for the five ideological positions are displayed. Several patterns emerge. The largest differences between voters and MPs are present on austerity issues and immigration. The general level of congruence is higher for left-right positions and EU attitudes. Comparing parties, the level of congruence between voters and MPs is greatest for the two government parties, ND and PASOK. All opposition parties display a far lower level of congruence, with SYRIZA the party having the largest differences between voters and MPs.

Going beyond these descriptive comparisons between parties, we conclude our analysis with an exploratory attempt to introduce a multi-variate perspective. In particular, we are interested in analysing whether once we control for the left-right position of voters and MPs, other dimensions actually make a difference or not. In other words, is the level of incongruence present in opposition parties mainly determined by the general left-right positioning of voters and MPs, or do attitudes to austerity and/or immigration feature as independent source of incongruence? In order to present a multi-variate analysis of congruence, we combine our two surveys and seek to 'predict' who is an MP and who is a voter on the basis of their positions on our five dimensions.

Unfortunately, the low number of cases we have makes a binary logistic regression potentially problematic. We thus present results of an exact logistic regression, a statistical technique that has become fairly popular in bio-medical research and is designed to produce reliable results for logistic regressions in studies with a small sample size (cf. Mehta \& Patel 1995; Hosmer, Lemeshow \& Sturdivant 2013, pp. 387-395). However, this technique is computationally rather intensive and calculations are not always successfully concluded. ${ }^{5}$ Exact logistic regressions could successfully be calculated for SYRIZA, ANEL and DIMAR. $^{6}$

The results for SYRIZA show clearly that left-right position and attitudes to immigration are the main determinants of the overall level of incongruence. Once these dimensions are controlled for, the austerity variables are not statistically significant predictors. The left-right dimension thus is more important than attitudes towards austerity but also the socio-cultural dimension plays an independent role. For ANEL, the reverse is the case as attitudes to austerity policies is the only statistically significant determinant of incongruence between voters and MPs. Finally, for DIMAR, the exact logistic regression confirms that attitudes the EU is the main source of differences between DIMAR voters and MPs, with voters adopting a more eurosceptic position than their MPs. 


\section{Conclusion}

This article has examined congruence between ideological positioning and attitudes to specific policy issues held respectively by Greek parliamentary representatives and their electorates at a time of economic crisis. The broad conclusion that has emerged is that congruence between MPs and voters varies both in intensity and direction depending upon whether left-right self-placement or substantive issue preferences - on austerity, EU integration or immigration - are used as measures of congruence.

Given the nature of our samples, our findings are indicative rather than definitive. Nonetheless, the results indicate that, in terms of left-right self-placement, there is broad congruence with parliamentarians, only marginally more extremely positioned ideologically than their voters. Only in the case of SYRIZA was the difference in self-placement particularly pronounced. Yet, if there is a broad congruence between voters and parties on left-right positioning there is no guarantee, as existing studies have already shown, that this will translate into congruence on attitudinal positioning on specific policy issues. While we found no major difference between voters and MPs on attitudes to European integration, which in itself is surprising given the belief that parliamentary elites are supposedly more pro-EU than ordinary voters, there was an apparent gap between the positions of voters and the positions of their party representatives on immigration. Voters of all parties displayed a broader range of positioning on this issue than their representatives; but, in terms of the direction of dissonance, far right MPs adopted more pronounced anti-immigration positions than their voters. At the other end of the ideological spectrum, however, SYRIZA MPs adopted stronger 'pro-' positions than their voters.

These findings mirror other studies that have already found different levels of MP-voter congruence between ideological self-placement and positioning in relation to specific policy preferences (see, for example, Freire \& Belchior 2013). Where our study has greater claims to novelty, however, is in its probing of attitudes towards austerity - both in terms of perceived threat and policy preferences. Here the average difference between MPs and voters was greater than for other scales of positioning, with the exception of immigration. What is particularly noteworthy about this finding is that there were divergences in the perception of threat and the level of support for austerity measures between voters for the main government parties and for the opposition parties. Congruence of austerity positions was greater for government parties (ND and PASOK) than for opposition parties. For the latter, the positions adopted by MPs were clearly more anti-austerity than those of their voters.

These results have important and tangible implications for party politics in Greece. Greek voters appear to adopt different positions across different policy/issue dimensions, which adds to the volatility of the representative process. This is particularly the case for SYRIZA. In the 2012 elections, a large section of the electorate turned to SYRIZA in what was seen as an anti-government and anti-austerity vote. Yet, our surveys clearly show that the attitudes of SYRIZA voters remained fairly distant from their representatives in parliament. In essence, many SYRIZA voters did not share the radical anti-austerity position, or the pro-immigration stance, adopted by SYRIZA MPs. The reported increase in support for SYRIZA in polls conducted in the summer of 2014 is most likely indicative of the party moderating its own positions, rather than taking its voters with it. At the other ideological extreme there was 
considerable incongruence between Golden Dawn voters and their parliamentary representatives, especially in their attitudes to austerity policies and the perception of threat posed by the Eurozone crisis, as well as to immigration. Golden Dawn MPs were significantly more anti-austerity and anti-immigration than their voters.

In this respect, the analysis of the Greek case highlights the importance of exploring issue dimensions beyond a simple left-right ideological dimension. The observed substantial variation in congruence, across parties and issue preferences in Greece, reinforces the view that the dimensionality of political contestation is not reducible to a single ideological dimension. This is particularly true at times of crisis and high political volatility, where positioning on austerity, immigration and European integration, move to centre stage in the dynamic process of linkage between represented and representatives. Our analysis reveals that there is no necessary correlation between the various dimensions. For instance, there are voters displaying pro-austerity and anti-immigration preferences who position themselves on the ideological 'left', while others placing themselves on the 'right' hold strong anti-austerity positions. The challenge for voters and parties alike is that dissonance across dimensions prompts matrix calculations of who to support (for voters) and where support is likely to come from (for parties). Our study is of significance in pointing to the complexity of representation - to the heterogeneity of positions across multi-dimensions and across and within parties - in times of crisis that simultaneously encompasses representational congruence and incongruence.

Future research might profitably consider the dynamics of simultaneous congruence and incongruence across multi-dimensions. Our study is of one point in time at one stage of crisis. Other studies are needed to examine how this relationship develops over time, of how attitudes and positions of voters and parties change diachronically and how voters perceive and prioritise their positions on some dimensions relative to others. Some of these avenues for future research have already been mapped from the perspective of voters and electoral behaviour (see Lefkofridi, Wagner \& Willmann 2014, Walgrave \& Lefevere 2013); our call is for further analysis of the nature of representational linkage beyond elections to incorporate studies of crosscutting pressures on parliamentarians in effecting policy choices and of how voters and representatives respond to perceived incongruence. 


\section{References}

Andeweg, R. B. (2011) 'Approaching perfect policy congruence: measurement, development, and relevance for political representation', in How Democracy Works: Political Representation and Policy Congruence in Modern Societies, eds M. Rosema, B. Denters \& K Aarts, Pallas Publications, Amsterdam, pp. 39-52.

Behnke, J. (2005) 'Lassen sich signifikanztests auf vollerhebungen anwenden? Einige essayistische anmerkungen', Politische Vierteljahresschrift, vol. 46, no. 1, pp. O_1-O_15.

Belchior, A. M. (2010) 'Ideological congruence among European political parties', Journal of Legislative Studies, vol. 16, no. 1, pp. 121-142.

Belchior, A. M. (2012) 'Explaining left-right party congruence across European party systems a test of micro-, meso-, and macro-level models', Comparative Political Studies, vol. 46, no 3, pp. 352-386.

Belchior, A. M. (2014) 'Explaining MPs' perceptions of voters' positions in a party-mediated representation system: evidence from the Portuguese case', Party Politics, vol. 20, no. 3, pp. 403-415.

Belchior, A. M. \& Freire, A. (2013) 'Is party type relevant to an explanation of congruence? catch-all versus ideological parties in the Portuguese case', International Political Science Review, vol. 34, no. 3, pp. 273-288.

Berk, R. A., Western, B. \& Weiss, R. E. (1995) 'Statistical inference for apparent populations', Sociological Methodology, vol. 25, pp. 421-458.

Broscheid, A. \& Gschwend, T. (2005). 'Zur statistischen Analyse von Vollerhebungen', Politische Vierteljahresschrift, vol. 46, no. 1, pp. O_16-O_26.

Clements, B., Nanou, K. \& Verney, S. (2014) "We no longer love you, but we don't want to leave you": the Eurozone crisis and popular euroscepticism in Greece', Journal of European Integration, vol. 36, no. 3, pp. 247-65.

Costello, R., Thomassen, J. \& Rosema, M. (2012) 'European parliament elections and political representation: policy congruence between voters and parties', West European Politics, vol. 35, no. 6, pp. 1226-1248.

Dalton, R. J. (1985) 'Political parties and political representation: party supporters and party elites in nine nations', Comparative Political Studies, vol. 18, no. 3, pp. 267-299.

Dalton, R. J., Farrell, D. M. \& McAllister, I. (2011) Political Parties and Democratic Linkage: How Parties Organize Democracy, Oxford University Press, Oxford.

de Vries, C. E., Hakhverdian, A. \& Lancee, B. (2013) 'The dynamics of voters' left/right identification: the role of economic and cultural attitudes', Political Science Research and Methods, vol. 1, no. 2, pp. 223-238.

Deschouwer, K. \& Depauw, S. (eds) (2014) Representing the People: A Survey among Members of Statewide and Sub-state Parliaments, Oxford University Press, Oxford.

Entman, R. M. (1993) 'Framing: toward clarification of a fractured paradigm', Journal of Communication, vol. 43, no. 4, pp. 51-58.

Esaiasson, P. \& Holmberg, S. (1996) Representation from Above: Members of Parliament and Representative Democracy in Sweden, Aldershot, Dartmouth.

Freeman, G. (1995) 'Modes of immigration politics in liberal democratic states', International Migration Review, vol. 29, no. 4, pp. 881-902.

Freire, A. (2008) 'Party polarization and citizens' left-right orientations', Party Politics, vol. 14, no. 2, pp. 189-209.

Freire, A. \& Belchior, A. (2013) 'Ideological representation in Portugal: MPs'-electors' linkages in terms of left-right placement and substantive meaning', Journal of Legislative Studies, vol. 19, no. 1, pp. 1-21.

Golder, M. \& Stramski, J. (2010) 'Ideological congruence and electoral institutions', American Journal of Political Science, vol. 54, no. 1, pp. 90-106.

Holmberg, S. (1989) 'Political representation in Sweden', Scandinavian Political Studies, vol. 12 , no. 1, pp. 1-36.

Hooghe, L. \& Marks, G. (2008) 'A Postfunctionalist theory of European integration: from permissive consensus to constraining dissensus', British Journal of Political Science, vol. 
39, no. 1, pp. 1-23.

Hooghe, L., Marks, G. \& Wilson, C. J. (2002) 'Does Left/Right Structure Party Positions on European Integration?', Comparative Political Studies, vol. 35, no. 8, pp. 956-989.

Hosmer, D.W. Jr., Lemeshow, S. \& Sturdivant, R. X. (2013) Applied Logistic Regression, $3^{\text {rd }}$ ed. , John Wiley \& Sons, Hoboken (N.J).

Huber, J. D. \& Powell, G. B. (1994) 'Congruence between citizens and policymakers in two visions of liberal democracy', World Politics, vol. 46, no. 3, pp. 291-326.

Iversen, T. (1994) 'The Logics of electoral politics: spatial, directional, and mobilization effects', Comparative Political Studies, vol. 27, no. 2, pp. 155-89.

Karyotis, G. \& Rüdig, W. (2013) 'Blame and punishment? The electoral politics of extreme austerity in Greece', Political Studies, published online 13 September 2013, DOI: 10.1111/1467-9248.12076.

Karyotis, G. \& Skleparis, D. (2013) 'Qui bono? The winners and losers of securitising migration', Griffith Law Review, vol. 22, no. 3, pp. 683-706.

Kirchheimer, O. (1966) 'The Transformation of the Western European Party Systems', in Political Parties and Political Development, eds J. LaPalombara \& M. Weiner, Princeton University Press, Princeton (N.J).

Kitschelt, H. (1994) The Transformation of Social Democracy, Cambridge University Press, Cambridge.

Lefkofridi, Z. \& Casado-Asensio, J. (2013) 'European vox radicis: representation and policy congruence on the extremes', Comparative European Politics, vol. 11, no. 1, pp. 93-118.

Lefkofridi, Z. \& Horvath, K. (2012) 'Migration policy issues and representation in European liberal democracies', Representation, vol. 48, no. 1, pp. 29-46.

Lefkofridi, Z., Wagner, N., \& Willmann, J. E. (2014) 'Left-authoritarians and policy representation in Western Europe: electoral choice across ideological dimensions', West European Politics, vol. 37, no. 1, pp. 65-90.

Maatch, A. (2014) 'Are we all austerians now? An analysis of national parliamentary parties' positioning on anti-crisis measures in the Eurozone', Journal of European Public Policy, vol. 21, no. 1, pp. 96-115.

Metha, C. R. \& Patel, N.R. (1995) 'Exact Logistic Regression: Theory and Example', Statistics in Medicine, vol. 14, no. 19, pp. 2143-2160.

Önnudóttir, E. H. (2014) 'Policy congruence and style of representation: party voters and political parties', West European Politics, vol. 37, no. 3, pp. 538-63.

Papadimitriou, D. \& Zartaloudis, S. (2015) 'European discourses on managing the Greek crisis: denial, distancing and blaming', in The Politics of Extreme Austerity, eds G. Karyotis \& R. Gerodimos, Palgrave Macmillan, London.

Pierce, R. (1999) 'Mass-elite issue linkages \& the responsible party model of representation', in Policy Representation in Western Democracies, eds W. E. Miller, R. Pierce, J. Thomassen, R. Herrera, S. Holmberg, P. Esaiasson, \& B. Wessels, Oxford University Press, Oxford, pp. 9-32

Rosema, M. \& de Vries, C.E. (2011) 'Assessing the quality of European democracy: are voters voting correctly?', in How Democracy Works: Political Representation and Policy Congruence in Modern Societies, eds M. Rosema, B. Denters \& K Aarts, Pallas Publications, Amsterdam, pp. 199-219.

Rüdig, W. (2010) 'Assessing Nonresponse Bias in Activist Surveys', Quality \& Quantity, vol. 44, no. 1, pp. 173-180.

Rüdig, W. \& Karyotis, G. (2014) 'Who protests in Greece? Mass opposition to austerity', British Journal of Political Science, vol. 44, no. 3, pp. 487-513.

Schmitt, H. \& Thomassen, J. (eds) (1999) Political Representation and Legitimacy in the European Union, Oxford University Press, Oxford.

Steenbergen, M.R., Edwards, E.E. \& de Vries, C. (2007) 'Who's cueing whom? Mass-elite linkages and the future of European integration', European Union Politics, vol. 8, no. 1, pp. 13-35.

Thomassen, J. (1999) 'Political communication between political elites and mass publics: The role of belief systems', in Policy Representation in Western Democracies, eds W. E. 
Miller, R. Pierce, J. Thomassen, R. Herrera, S. Holmberg, P. Esaiasson, \& B. Wessels, Oxford University Press, Oxford.

Thomassen, J. (2012) 'The blind corner of political representation', Representation, vol. 48, no. 1, pp.13-27.

Thomassen, J. \& van Ham, C. (2014) 'Failing political representation or a change in kind? Models of representation and empirical trends in Europe', West European Politics, vol. 37, no. 2, pp. 400-19.

van der Brug, W. \& van Spanje, J. (2009) 'Immigration, Europe and the "new socio-cultural dimension", European Journal of Political Research, vol. 48, no. 3, pp. 309-334.

Verney, S. (2014) "'Broken and can't be fixed": the impact of the economic crisis on the Greek party system', The International Spectator: Italian Journal of International Affairs, vol. 49, no. 1, pp. 18-35.

Walgrave, S. \& Lefevere, J. (2013) 'Ideology, salience, and complexity: determinants of policy issue incongruence between voters and parties', Journal of Elections, Public Opinion and Parties, vol. 23, no. 4, pp. 456-483. 


\section{Appendix: Question Wording}

\section{Left-Right Placement}

In politics people sometimes talk of "left" and "right". Where would you place yourself on this $0-10$ scale, where 0 means the left and 10 means the right?

\section{Severity of Threat:}

There are different views about how serious a threat the current crisis poses to Greece's future. On a scale from 0 to 10 , where 0 means that the threat is vastly exaggerated and 10 means that Greece's national survival is seriously at risk, which number describes your position?

\section{Positions on Austerity:}

Imagine a scale from 0 to 10 , where 0 means to completely abandon austerity in Greece and risk leaving the Euro, and 10 means to accept whatever austerity measures are necessary to stay in the Eurozone. Which number best describes your position on this scale?

\section{European Integration:}

Some say European unification should be pushed further. Others say it already has gone too far. What is your opinion? On the same scale from 0 to 10 , where 0 means unification 'has already gone too far' and 10 means it 'should be pushed further', what is your position?

\section{Immigration:}

To what extent do you agree or disagree with the following...

b. Immigrants are generally good for the Greek economy.

d. Immigrants increase crime rates

(strongly agree, agree, neither agree nor disagree, disagree, strongly disagree)

\section{Party or Vote Choice:}

For Elites: What party do you currently represent?

For Voters: Which party did you vote for in the 17 June 2012 Parliamentary elections? 
Figure 1: Comparing Voters and MPs*

a) Left-Right Positioning
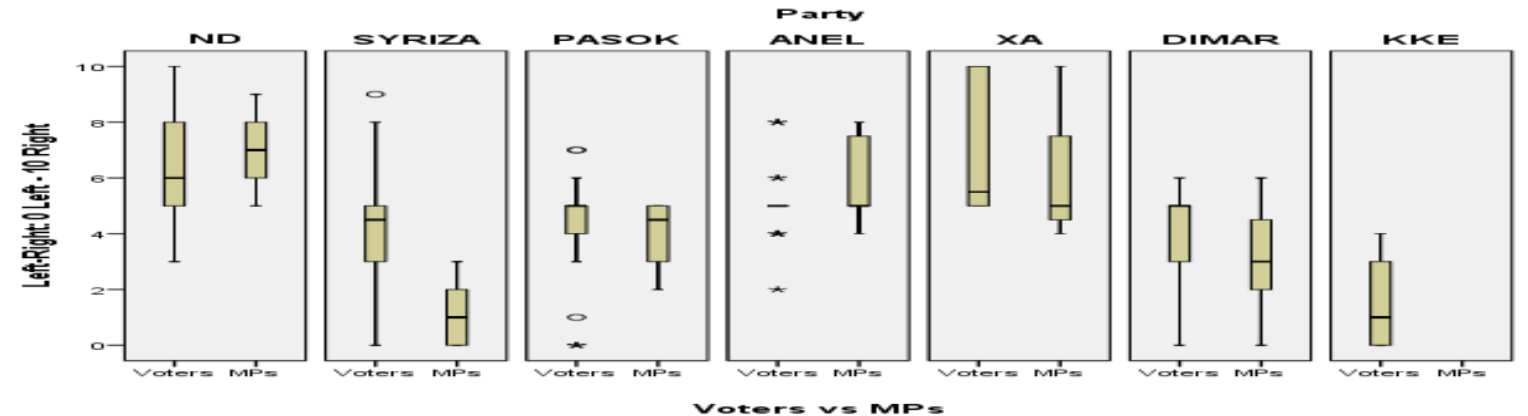

b) Perception of the Degree of Threat Involved in the Debt Crisis
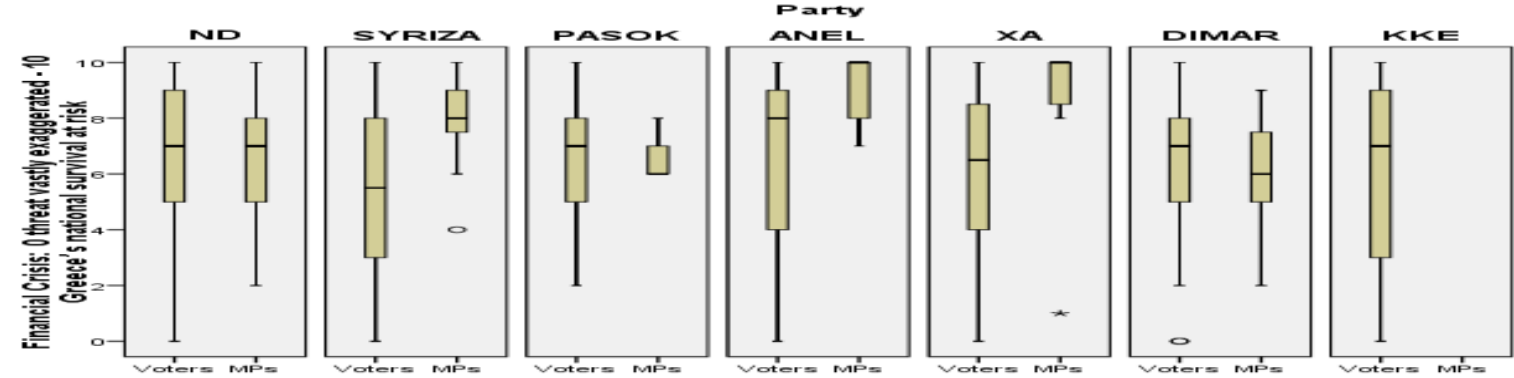

c) Attitudes to Austerity Policies
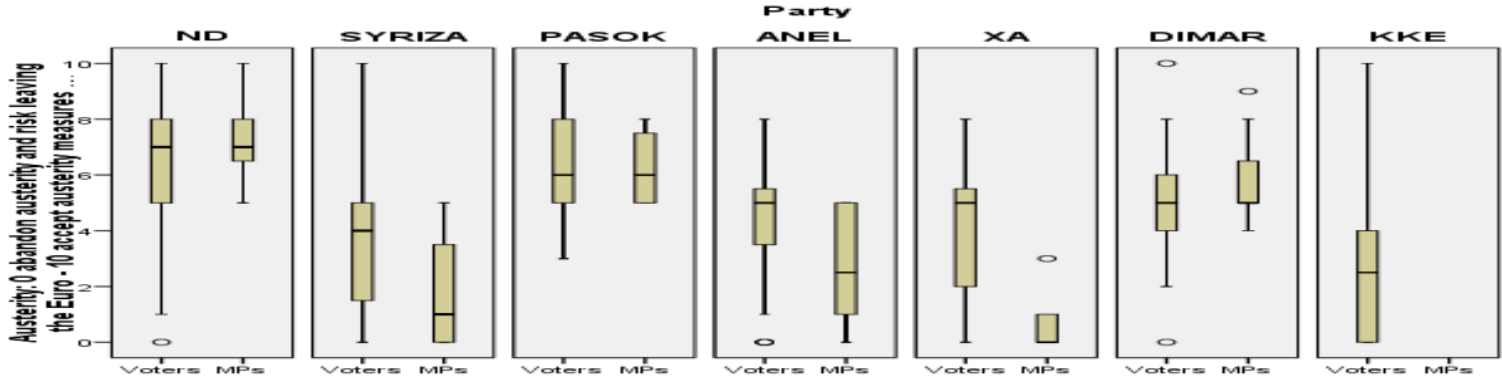

d) Attitudes to European Integration
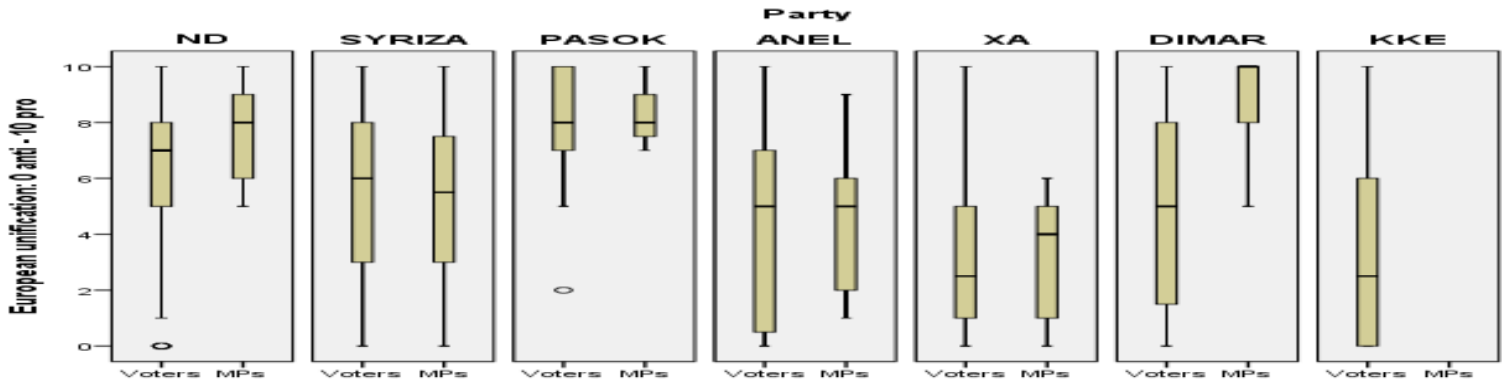

e) Attitudes to Immigration
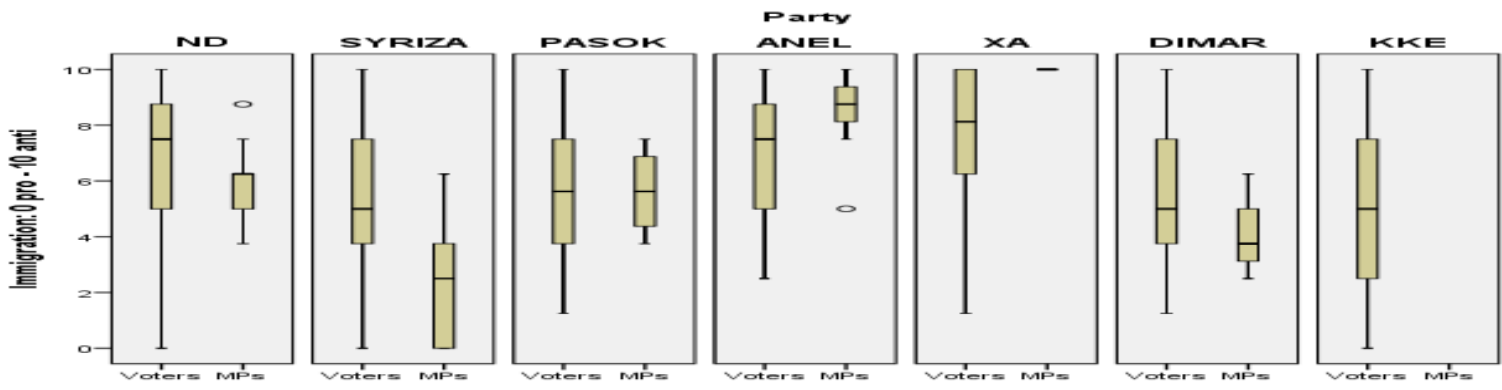

*The figures show 'boxplots'. The thick horizontal line identifies the median; the box indicates the range of $50 \%$ of the responses, while the bottom and top horizontal lines indicate the minimum and maximum values, respectively; a circle indicates a mild outlier, an asterisk an extreme outlier; for abbreviations (party names), see Table 1. Source: Own data. 
Table 1 Response Rates, MPs Survey, July 2013

\begin{tabular}{|l|l|l|l|l|}
\hline Party & Position & $\begin{array}{l}\text { Number of } \\
\text { MPs }\end{array}$ & Respondents & Response rate \\
\hline New Democracy (ND) & Government & 127 & 15 & $11.8 \%$ \\
\hline $\begin{array}{l}\text { Panhellenic Socialist } \\
\text { Movement (PASOK) }\end{array}$ & Government & 28 & 4 & $14.3 \%$ \\
\hline $\begin{array}{l}\text { Coalition of the Radical } \\
\text { Left (SYRIZA) }\end{array}$ & Opposition & 72 & 20 & $\begin{array}{l}\text { Gov. parties: } \\
12.2 \%\end{array}$ \\
\hline Golden Dawn (XA) & Opposition & 18 & 7 & $27.8 \%$ \\
\hline $\begin{array}{l}\text { Independent Greeks } \\
\text { ANEL) }\end{array}$ & Opposition & 18 & 12 & $38.9 \%$ \\
\hline $\begin{array}{l}\text { Democratic Left (DIMAR) } \\
\text { Opposition } \\
\text { (since June } \\
\text { 2013) }\end{array}$ & 14 & 11 & $66.6 \%$ \\
\hline $\begin{array}{l}\text { Communist Party of } \\
\text { Greece (KKE) }\end{array}$ & Opposition & 12 & 0 & $0.0 \%$ (refused) \\
\hline Independents & Opposition & 11 & 3 & $16.7 \%$ \\
\hline & & & $\begin{array}{l}\text { Opp. } \\
\text { (excl. } \\
39.8 \%\end{array}$ \\
\hline Unknown affiliation & & 300 & 77 & $\begin{array}{l}\text { Total } \\
\text { KKE): 26.7\% }\end{array}$ \\
\hline
\end{tabular}

Source: Own data. 
Table 2 Differences in the Positions of Voters and MPs (Difference of Means and Exact Logistic Regression Coefficients)*

\begin{tabular}{|c|c|c|c|c|c|c|c|c|c|c|c|c|}
\hline & \multicolumn{2}{|c|}{ ND } & \multicolumn{2}{|c|}{ SYRIZA } & \multicolumn{2}{|c|}{ PASOK } & \multicolumn{2}{|c|}{ ANEL } & \multicolumn{2}{|c|}{ XA } & \multicolumn{2}{|c|}{ DIMAR } \\
\hline & \begin{tabular}{l} 
Difference \\
of Mean \\
(Voter-MP) \\
\multicolumn{1}{c}{$(1)$}
\end{tabular} & $\begin{array}{l}\text { Exact } \\
\text { Logistic } \\
\text { Regression } \\
\text { Co-efficient } \\
\quad(2)\end{array}$ & $\begin{array}{l}\text { Difference } \\
\text { of Mean } \\
\text { (Voter-MP) } \\
\qquad(3)\end{array}$ & $\begin{array}{l}\text { Exact } \\
\text { Logistic } \\
\text { Regression } \\
\text { Co-efficient } \\
\quad(4)\end{array}$ & $\begin{array}{l}\text { Difference } \\
\text { of Mean } \\
\text { (Voter-MP) } \\
\quad(5)\end{array}$ & $\begin{array}{l}\text { Exact } \\
\text { Logistic } \\
\text { Regression } \\
\text { Co-efficient } \\
\quad(6)\end{array}$ & 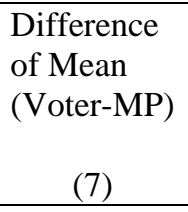 & $\begin{array}{l}\text { Exact } \\
\text { Logistic } \\
\text { Regression } \\
\text { Co-efficient } \\
\quad(8) \\
\end{array}$ & 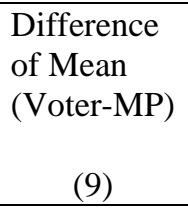 & $\begin{array}{l}\text { Exact } \\
\text { Logistic } \\
\text { Regression } \\
\text { Co-efficient } \\
\quad(10) \\
\end{array}$ & $\begin{array}{l}\text { Difference } \\
\text { of Mean } \\
\text { (Voter-MP) } \\
\quad(11)\end{array}$ & $\begin{array}{l}\text { Exact } \\
\text { Logistic } \\
\text { Regression } \\
\text { Co-efficient } \\
\quad(12) \\
\end{array}$ \\
\hline Left-Right & -0.33 & NA & $2.88 * * *$ & $-.745 * *$ & 0.27 & NA & -0.83 & .207 & 0.75 & NA & 0.90 & -.265 \\
\hline Austerity & -0.75 & NA & $1.64 *$ & .132 & 0.18 & $\mathrm{NA}$ & $1.64 *$ & $-.891 *$ & $3.29 * *$ & $\mathrm{NA}$ & -0.77 & .010 \\
\hline $\mathrm{EU}$ & -0.94 & NA & 0.21 & -.008 & -0.12 & NA & -0.36 & .114 & 0.22 & NA & $-3.79 * *$ & $.424 * *$ \\
\hline Immigration & 0.78 & NA & $3.73 * * *$ & $-.436 *$ & 0.08 & NA & -1.49 & .069 & $-2.19 * *$ & $\mathrm{NA}$ & $1.54 *$ & -.360 \\
\hline $\begin{array}{l}\text { Average } \\
\text { difference } \\
\text { (means) }\end{array}$ & 0.62 & - & 2.19 & - & 0.15 & - & 1.35 & - & 1.77 & - & 1.50 & - \\
\hline $\begin{array}{l}\mathrm{N} \\
\text { (Average) }\end{array}$ & 114 & - & 98 & 70 & 51 & - & 41 & 32 & 24 & - & 50 & 43 \\
\hline
\end{tabular}

"Cell entries in columns 1,3,5,7, 9 and 11 display differences in means between voters and MPs, and the results of the Wilcoxon-Mann-Whitney test, * $\mathrm{p}<0.05 * * \mathrm{p}<0.01 * * * \mathrm{p}<0.001$; cell entries in columns 4, 8 and 12 display exact logistic regression co-efficients, dependent variable: voters 0 , MPs 1 ; statistically significant results are in bold, $* \mathrm{p}<0.05 * * \mathrm{p}<0.01 * * * \mathrm{p}<0.001$.

Source: Own data. 
${ }^{1}$ The use of tests of statistical significance in comparing our data on voters and MPs raises some important methodological questions. First, the survey of MPs was a 'full survey' of the entire 'population' of MPs and, assuming there is no significant non-response bias, the results should thus be fully representative of the population of MPs. In this context, it could be argued that the use of tests of statistical significance is inappropriate (cf. Berk, Western \& Weiss 1995). In our case, we are comparing the results from one source not involving a sampling process (MPs) with another source with data derived from a random population sample (voters). Therefore, the use of tests of significance may be justified. However, given the continued debate about the value of significance tests in general and their application to 'full surveys' not involving a sampling process in particular (cf. Behnke 2005; Broscheid and Gschwend 2005), care should be taken not too rely too strongly on the results of statistical significance tests for any substantive conclusions.

Second, there is the question which statistic test is appropriate for comparing the distribution from two independent surveys. We calculated both the two independent samples t-test of the difference of means and the Wilcoxon-Mann-Whitney test of the differences in the underlying distribution. Both produce virtually identical results but as the latter is far more conservative in its assumptions, we rely on the results of the Wilcoxon-Mann-Whitney test as an indication of the presence of a statistically significant difference in the underlying distributions in the positioning of voters and MPs on our five attitudinal dimensions.

${ }^{2}$ This also shows the limitation of conceiving Left-Right as a super issue, when it may include both an economic and a libertarian/authoritarian dimension, among others. Golden Dawn is on the extreme right on the latter but they have unclear positions on the former.

${ }^{3}$ This comparison between voters and all MPs only includes voters of the parties for which we have data on MPs (i.e. excluding KKE and minor parties), with the data on MPs weighted according to their representation in parliament.

${ }^{4}$ Both items have been used in several surveys to measure attitudes to immigration as part of a four item scale. Cronbach's alpha for these two items is .559. Adding the scores of both questions (recoded for direction) produced a scale from 2-10 which was transformed into 010 scale with the formula $y=(x-2)(8 / 10)$ to facilitate comparison with the other variables.

${ }^{5}$ For ND and PASOK, the complete absence of any statistically significant differences between the positioning of voters and MPs for all dimensions makes a multi-variate analysis in any case redundant. For Golden Dawn, a regression analysis would have been of interest but the regression model does not compute, presumably because of a combination of a very low number of cases and highly unbalanced data. For example, all Golden Dawn MPs selected the most extreme option for immigration.

${ }^{6}$ The models were fitted with STATA 13 using the exlogistic command; binary logistic regressions were also conducted and produced very similar results. The only difference was that one variable, the threat of austerity, was a statistically significant predictor for SYRIZA in the binary model but not in the exact logistic regression model. 